Original Article

\title{
Thermo-resistant enzyme-producing microorganisms isolated from composting
}

\author{
Microrganismos produtores de enzimas termo-resistentes isolados de compostagem
}

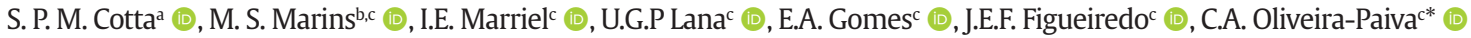 \\ aPrograma de Mestrado Profissional em Biotecnologia e Gestão da Inovação, Departamento de Ciências Biológicas, Centro Universitário de Sete \\ Lagoas, UNIFEMM, Sete Lagoas, MG, Brasil \\ bPrograma de Microbiologia Agrícola, Departamento de Biologia, Universidade Federal de Lavras - UFLA, Lavras, MG, Brasil \\ cLaboratório de Microbiologia e Biologia Molecular Embrapa Milho e Sorgo, CNPMS/Embrapa, Sete Lagoas, MG, Brasil
}

\begin{abstract}
Organo-mineral fertilizers supplemented with biological additives are an alternative to chemical fertilizers. In this study, thermoresistant microorganisms from composting mass were isolated by two-step procedures. First, samples taken at different time points and temperatures ( 33 days at $52{ }^{\circ} \mathrm{C}, 60$ days at $63{ }^{\circ} \mathrm{C}$, and over 365 days at $26^{\circ} \mathrm{C}$ ) were pre-incubated at $80^{\circ} \mathrm{C}$ for 30 minutes. Second, the microbial selection by in vitro culture-based methods and heat shock at $60{ }^{\circ} \mathrm{C}$ and $100{ }^{\circ} \mathrm{C}$ for $2 \mathrm{~h}$ and $4 \mathrm{~h}$. Forty-one isolates were able to grow at $60{ }^{\circ} \mathrm{C}$ for $4 \mathrm{~h}$; twenty-seven at $100{ }^{\circ} \mathrm{C}$ for $2 \mathrm{~h}$, and two at $100^{\circ} \mathrm{C}$ for $4 \mathrm{~h}$. The molecular identification by partial sequencing of the $16 \mathrm{~S}$ ribosomal gene using universal primers revealed that thirty-five isolates were from eight Bacillus species, one Brevibacillus borstelensis, three Streptomyces thermogriseus, and two fungi (Thermomyces lanuginosus and T. dupontii). Data from amylase, phytase, and cellulase activity assays and the enzymatic index (EI) showed that 38 of 41 thermo-resistant isolates produce at least one enzyme. For amylase activity, the highest EI value was observed in Bacillus licheniformis (isolate 21C2, EI=4.11), followed by Brevibacillus borstelensis (isolate 6C2, EI= 3.66), Bacillus cereus (isolate 18C2, EI= 3.52), and Bacillus paralicheniformis (isolate 20C2, EI=3.34). For phytase, the highest EI values were observed for Bacillus cereus (isolate $18 \mathrm{C2}$, EI= 2.30) and Bacillus licheniformis (isolate $3 \mathrm{C} 1$, $\mathrm{EI}=2.15$ ). . Concerning cellulose production, $B$. altitudinis (isolate $6 \mathrm{C} 1$ ) was the most efficient $(\mathrm{EI}=6.40)$, followed by three Bacillus subtilis (isolates 9C1,16C2, and 19C2) with EI values of 5.66,5.84, and 5.88, respectively, and one B. pumilus (isolate $27 \mathrm{C} 2, \mathrm{EI}=5.78$ ). The selected microorganisms are potentially useful as a biological additive in organo-mineral fertilizers and other biotechnological processes.
\end{abstract}

Keywords: thermal-resistant microorganisms, organo-mineral fertilizers, microbial enzymes.

\begin{abstract}
Resumo
Os fertilizantes organo-minerais suplementados com aditivos biológicos são uma alternativa aos adubos químicos. Neste estudo, microrganismos termoresistentes foram isolados de compostagem por procedimentos de duas etapas. Inicialmente, as amostras tomadas em diferentes períodos e temperaturas ( 33 dias a $52{ }^{\circ} \mathrm{C}, 60$ dias a $63^{\circ} \mathrm{C}$ e mais de 365 dias a $26^{\circ} \mathrm{C}$ ) foram pré-incubadas a $80^{\circ} \mathrm{C}$ por 30 minutos. Posteriormente, a seleção microbiana foi conduzida por métodos baseados em cultura in vitro e choque térmico a $60^{\circ} \mathrm{C}$ e $100^{\circ} \mathrm{C}$ por $2 \mathrm{~h}$ e $4 \mathrm{~h}$. Quarenta e um isolados foram capazes de crescer a $60^{\circ} \mathrm{C}$ por $4 \mathrm{~h}$; vinte e sete a $100^{\circ} \mathrm{C}$ por $2 \mathrm{~h}$ e dois a $100^{\circ} \mathrm{C}$ por $4 \mathrm{~h}$. A identificação molecular por sequenciamento parcial do gene ribossomal $16 \mathrm{~S}$ usando primers universais revelou que trinta e cinco isolados eram de oito espécies de Bacillus, um Brevibacillus borstelensis, três Streptomyces thermogriseus e dois fungos (Thermomyces lanuginosus e T. dupontii). Os dados dos ensaios de atividade de amilase, fitase e celulase e 0 índice enzimático (IE) mostraram que 38 dos 41 isolados termorresistentes produziram pelo menos uma enzima. Para a atividade da amilase, o maior valor de IE foi observado em Bacillus licheniformis (isolado 21C2, IE = 4,11), seguido por Brevibacillus borstelensis (isolado $6 C 2$, IE = 3,66), Bacillus cereus (isolado $18 C 2$, IE $=3,52$ ) e Bacillus paralicheniformis (isolado 20C2, IE = 3,34). Para a fitase, os maiores valores de IE foram observados para $B$. cereus (isolado $18 \mathrm{C} 2, \mathrm{IE}=2,30$ ) e $B$. licheniformis (isolado $3 C 1, \mathrm{IE}=2,15$ ). Em relação à produção de celulose, $B$. altitudinis (isolado 6C1) foi o mais eficiente (IE = 6,40), seguido por três Bacillus subtilis (isolados 9C1, 16C2 e 19C2) com valores de IE de 5,66, 5,84 e 5,88, respectivamente, e um $B$. pumilus (isolado $27 \mathrm{C} 2$, IE $=5,78$ ). Pode-se inferir que os microrganismos selecionados são potencialmente úteis como aditivos biológicos em fertilizantes organo-minerais e outros processos biotecnológicos.
\end{abstract}

Palavras-chave: microrganismos termoresistentes, Fertlizantes organo-minerais, enzimas microbianas.

*e-mail: christiane.paiva@embrapa.br

Received: October 7, 2020 - Accepted: March 27, 2021

This is an Open Access article distributed under the terms of the Creative Commons Attribution License, which permits unrestricted use, distribution, and reproduction in any medium, provided the original work is properly cited. 


\section{Introduction}

The agricultural sector exerts a strong influence over the Brazilian economy, contributing positively to the trade balance. In 2019, the sector accounted for $43.2 \%$ of the Brazilian exports, which corresponded to US $\$ 96.79$ billion to the balance of trade (ECLAC, 2019). Estimates indicate that by 2024, Brazil will be the largest exporter of food globally (OECD, 2015; Macedo \& Nishizaki Júnior, 2017). However, the low availability of nutrients in the Brazilian soils with low amounts of nutrients such as nitrogen $(\mathrm{N})$, phosphorus $(\mathrm{P})$, and potassium $(\mathrm{K})$ is a limiting factor for the development and expansion of agriculture in the country. The low concentrations of available phosphorus in these soils occur due to depletion and run-off carried out over time (Camenzind et al., 2018). Chemical fertilizers are widely used to correct the P deficiency in the soil, but their long-term application is often cumulative, leading to environmental degradation due to eutrophication, which poses a severe threat to water bodies reducing the biodiversity of the aquatic ecosystem (Mastrorilli and Zucaro, 2016; Huang et al., 2017; Jarvie et al., 2018; Bhatt et al., 2019). Also, the high costs of chemical fertilizers is a limiting factor for large-scale food production in Brazil (Martinelli and Filoso, 2009; Mondal et al., 2017; Pivoto et al., 2018). Therefore, due to global restrictions on commodities grown in Brazil the great challenge facing the Brazilian agricultural sector in the near future is to reduce costs and risks by increasing crop productivity in a sustainable way (Pereira et al., 2012; OECD, 2015; Mastrorilli and Zucaro, 2016).

In general, Brazilian soils are impoverished in nutrients necessary for the commercial production of plant foods. The country imports $75 \%$ of the fertilizer used to produce food (Galembeck et al., 2019). In the year 2019, the Brazilian fertilizer imports hit a record with the purchases totalizing 31 million tons, spending the US\$ 9 billion, and the expectation is that these numbers will continue to increase (Vegro, 2018; BrasilAgro, 2020). Brazil is a country that depends on agriculture, and not producing fertilizer is a significant strategic mistake. The leading fertilizer suppliers to Brazil were Russia, Canada, China, and Morocco, which means that disruption in the supply chain, will lead to significant production problems (Cella and Ross, 2010).

In recent years, a great effort has been devoted to developing and implementing innovative strategies based on eco-friendly products for soil fertilization. The development and implementation of innovative strategies based on eco-friendly products for soil fertilization is a pressing challenge for sustainable agriculture in Brazil since $75 \%$ of the fertilizers used in the country are imported (Bhardwaj et al., 2014; Radl et al., 2015; Anda, 2016; Uvarov et al., 2016; Abreu et al., 2017; Correa et al., 2018; Withers et al., 2018). The use of composting technology to produce organo-mineral fertilizers is a low cost and promising solution to ameliorate the environmental pollution problems associated with organic agricultural wastes (Milala et al., 2005; Higashikawa et al., 2010; Shukor et al., 2018). Furthermore, organo-mineral fertilizers have advantages over mineral- derived fertilizers by improving the soil physicochemical properties and even increasing crop yields (Correa et al., 2018). However, one of the limitations of using organomineral technology is the increase in temperature of up to $104{ }^{\circ} \mathrm{C}$ during the granulation process that inactivates heat-sensitive microorganisms (Morais, 2014).

Thermophilic microorganisms can grow at elevated temperatures above $45^{\circ} \mathrm{C}$ to $70^{\circ} \mathrm{C}$, with optima between $50^{\circ} \mathrm{C}$ and $60^{\circ} \mathrm{C}$, and may be found occupying several habits like hot spring, deep-sea hydrothermal vents, peat bogs, and composting (Hartmann et al., 1989; Panikov et al., 2003; Eze et al., 2011; Zeldes et al., 2015; Counts et al., 2017). In composting, the microbial population degrades organic matter through enzymatic reactions under specific conditions of temperature, moisture, $\mathrm{pH}$, and time, making the compound a stable product (Insam and Bertoldi, 2007; Ribeiro et al., 2017). In the thermophilic phase of composting, the high temperature favors heat-resistant microbial populations (Gou et al., 2017; Xu et al., 2019). This work aimed to select thermophilic enzyme-producer microorganisms from composting mass, aiming their use in the formulation of organo-mineral fertilizers.

\section{Material and Methods}

\subsection{Isolation, counting, and morphological characterization of microorganisms}

The samples were collected in triplicate from three rows of organic composting, at three different points in a vegetable production area monitored by the Empresa de Assistência Técnica e Extensão Rural do Estado de Minas Gerais, EMATER-MG.

For isolating the thermo-resistant morphotypes, the collected samples were homogenized, diluted in saline solution ( $\mathrm{NaCl} 0.85 \%$ ), and dilutions of $10^{-1}$ were subjected to $80{ }^{\circ} \mathrm{C}$ for 30 minutes under agitation at 120 rotations per minute (Shair, 2014). Then, aliquots of $0.1 \mathrm{~mL}$ were transferred to potato dextrose agar (PDA) for bacteria isolation and enumeration using $10^{-4}$ and $10^{-6}$ duplicate dilutions (Beever and Bollard, 1970). The fungi isolation was performed in the Martin medium, containing $1 \mathrm{~mL} / \mathrm{L}$ streptomycin at $10^{-2}$ and $10^{-4}$ dilutions, in duplicate. For the isolation and counting of actinomycetes, sample dilutions of $10^{-4}$ and $10^{-6}$ were plated in duplicate in a specific medium containing L-asparagine, 1 g. $\mathrm{L}^{-1}$; glycerol, 10 g.L.- $; \mathrm{KH}_{2} \mathrm{PO}_{4}, 1$ g.L. $\mathrm{L}^{-1}$; plus $100 \mathrm{mg} / 100 \mathrm{ml}$ of each of the following micronutrients: $\mathrm{FeSO}_{4} \cdot 7 \mathrm{H}_{2} \mathrm{O}, \mathrm{MnCl}_{2} \cdot 4 \mathrm{H}_{2} \mathrm{O}$, and $\mathrm{ZnSO}_{4} \cdot 7 \mathrm{H}_{2} \mathrm{O}$. Then, $15 \mathrm{~g} / \mathrm{L}$ of bacteriological agar and $5 \mathrm{~mL} / \mathrm{L}$ of cycloheximide $(0.6 \% \mathrm{p} / \mathrm{v})$ solution was added to the medium.

After incubation of the plated samples at $47 \pm 1{ }^{\circ} \mathrm{C}$ for three days for bacteria, and five days (120h) for fungi and actinomycetes, the number of bacteria, fungi, and actinomycetes forming colonies were counted, and the result was expressed in Colony-Forming Units (CFU). $\mathrm{g}^{-1}$ of the sample. The bacterial colonies were characterized morphologically, according to the Management Manual for the Collection of Multifunctional and Phytopathogenic Microorganisms (CMMF) from the Embrapa Milho e Sorgo 
(Paiva et al., 2013). The colonies of bacteria, fungi, and actinomycetes were grouped according to morphology similarities and dissimilarities in an EZ-4 LEICA stereomicroscope. The selected colonies of bacteria and actinomycetes were transferred to Nutrient Agar, incubated at $47 \pm 1^{\circ} \mathrm{C}$, and preserved in mineral oil.

\subsection{Evaluation of the thermal tolerance at temperatures above $50^{\circ} \mathrm{C}$}

Pure colonies of bacteria, fungi, and actinomycetes isolated in the previous step were suspended in sterile $0.85 \%$ saline and diluted to $10^{-3}$ and $10^{-5}$ in Soy Trypticaseine Broth (STB) medium. Then, two replicates of $0.1 \mathrm{~mL}$ of each sample were incubated at $60^{\circ} \mathrm{C}$ and $105 \pm 5^{\circ} \mathrm{C}$ for $2 \mathrm{~h}$ and $4 \mathrm{~h}$. These bacterial colonies were counted by duplicate dilutions of $10^{-2}$ and $10^{-3}$. Bacteria incubated at $105 \pm$ $5{ }^{\circ} \mathrm{C}$ were counted by dilution of $10^{-1}$. For actinomycetes and fungi, only the presence or absence of growth was annotated.

\subsection{Evaluation of enzyme production}

The microorganisms showing better heat-resistance to incubation at $60{ }^{\circ} \mathrm{C}$ and $100{ }^{\circ} \mathrm{C}$ for $2 \mathrm{~h}$ and $4 \mathrm{~h}$ were inoculated, in triplicate, in Petri dishes containing specific solid media for induction of each enzyme. The inoculated plates were incubated in a shaking incubator at $47 \pm 1^{\circ} \mathrm{C}$ for 7 days for amylase and phytase, and 10 days for cellulase. After incubation, colonies and halo diameters were measured in centimeters to estimates the Enzyme Index (EI), and expressed by the relationship between the average colony diameter and the average halo diameter. The Starch Agar medium was used for testing amylase production, Phytase production was evidenced in the phytate medium (Pikovskaya, 1948), and for cellulase production, the microorganisms were inoculated in a solid medium supplemented with carboxymethylcellulose (CMC) as the only carbon source (SILVA et al., 2015).

\subsection{Statistical analysis}

The statistical analysis was performed with the aid of the SISVAR program (Ferreira, 2008). The data were subjected to analysis of variance (ANOVA) with three repetitions and the means compared using the Scott-Knott test at 5\% probability level $(\mathrm{p}<0.05)$. The estimation of the enzymatic index (EI) was according to a completely randomized design.

\subsection{Molecular characterization}

\subsubsection{Bacterial and actinobacteria $16 \mathrm{~S}$ rDNA amplification}

GenomicDNA of bacterial and actinomycetes was extracted using the Promega Wizard Genomic DNA Purification Kit following the manufacturer's instructions. The $16 \mathrm{~S}$ universal primers 8F (5'-AGAGTTTGATCCTGGCTCAG-3') and 1492R (5'-GGTTACCTTGTTACGACTT-3') were used in PCR reactions. The reaction consisted of $40 \mathrm{ng}$ of DNA, 1X Promega buffer, $1.5 \mathrm{mM} \mathrm{MgCl}_{2}, 0.125 \mathrm{mM}$ dNTP, 4\% (v/v) dimethyl sulfoxide (DMSO), $0.4 \mu \mathrm{M}$ of each primer and 1 unit of Taq DNA polymerase (Invitrogen, Carlsbad, CA, USA) in a final volume of $20 \mu \mathrm{L}$. The amplification conditions were
$95{ }^{\circ} \mathrm{C}$ for 2 min followed by 35 cycles of $94{ }^{\circ} \mathrm{C}$ for $30 \mathrm{sec}$, $59{ }^{\circ} \mathrm{C}$ for $30 \mathrm{sec}$, and $72{ }^{\circ} \mathrm{C}$ for $90 \mathrm{sec}$, followed by a final elongation step at $72^{\circ} \mathrm{C}$ for $10 \mathrm{~min}$. The amplicons were checked in agarose gel electrophoresis $1 \%(\mathrm{w} / \mathrm{v})$ in TAE $1 \mathrm{X}$ buffer (Tris-acetate-EDTA), and purified with ExoSAP-IT one-step solution (Applied Biosystems).

\subsubsection{PCR amplification of the fungal internal transcribed spacer(ITS)}

The extraction of fungal genomic DNA was according to the CTAB method described by Doyle and Doyle (1990). The amplification of the fungal ITS region the universal primers ITS4 (5'-TCCTCCGCTTATTGATATGC-3') and ITS5 (5'-GGAAGTAAAAGTCGTAACAAGG-3') were used. The PCR reactions were performed with 20 ng of DNA, $1 \mathrm{X}$ buffer, $2.0 \mathrm{mM} \mathrm{MgCl}, 0.125 \mathrm{mM}$ dNTP, $0.5 \mu \mathrm{M}$ of each primer, and 1 unit of Taq DNA polymerase (Invitrogen, Carlsbad, CA, USA). The amplification conditions were $95^{\circ} \mathrm{C}$ for $2 \mathrm{~min}$ followed by 35 cycles of $94^{\circ} \mathrm{C}$ for $1 \mathrm{~min}, 55^{\circ} \mathrm{C}$ for $30 \mathrm{sec}$, and $72{ }^{\circ} \mathrm{C}$ for $1 \mathrm{~min}$, and a final elongation step at $72{ }^{\circ} \mathrm{C}$ for $10 \mathrm{~min}$. Amplicons were resolved by agarose gel electrophoresis $1 \%(\mathrm{w} / \mathrm{v})$ in TAE $1 \mathrm{X}$ buffer (Tris-acetateEDTA), and purified with ExoSAP-IT one-step solution (Applied Biosystems).

\subsubsection{DNA Sequencing}

The sequencing reactions were performed with the BigDye Terminator v3.1 Cycle Sequencing Kit according to the manufacturer instructions (Applied Biosystems), and the sequencing run was in an ABI PRISM 3500XL Genetic Analyzer (Applied Biosystems). The nucleotide sequences were aligned and edited by Sequencher 4.1 program, and the species identity determined by the Blastn algorithm located in NCBI (https://www.ncbi.nlm.nih.gov/). The edited sequences were compared with the nucleotide sequences deposited in the GenBank database. The rDNA sequences have been registered in the GenBank database under accession numbers shown in Table 1.

\section{Results}

\subsection{Isolation, counting, and morphological} characterization of heat-resistant microorganisms from composting mass

The average temperature of the C1 sample ( $33^{\text {th }}$ day) was $51.9{ }^{\circ} \mathrm{C}$, with counts of $4.0 \times 10^{7} \mathrm{CFU}^{-1} \mathrm{~g}^{-1}$ for bacteria, $2.0 \times 10^{7} \mathrm{CFU} / \mathrm{g}^{-1}$ for actinomycetes, and $1.1 \times 10^{3} \mathrm{CFU}^{-1}{ }^{-1}$ for fungi. The sample $\mathrm{C} 2\left(60^{\text {th }}\right.$ day) showed an average temperature of $63 \pm 1^{\circ} \mathrm{C}$ and counts of $5.8 \times 10^{6} \mathrm{CFU}^{-1}, 1.8 \times 10^{6} \mathrm{CFU}^{-1}{ }^{-1}$, and $1.7 \times 10^{5} \mathrm{CFU}^{-1} \mathrm{~g}^{-1}$ for bacteria, actinomycetes, and fungi, respectively. The sample $\mathrm{C} 3$ (more than 12 months), the temperature was $25 \pm 1{ }^{\circ} \mathrm{C}$, and its microbial community was more sensitive to rising temperature $\left(80^{\circ} \mathrm{C}\right)$, with a count of $1.0 \times 10^{5} \mathrm{UFC}^{-g^{-1}}$ of bacteria and absence of fungi and actinomycetes. We succeeded in isolating 105 microorganisms: 85 from bacteria, 20 from actinomycetes, and two fungi. 


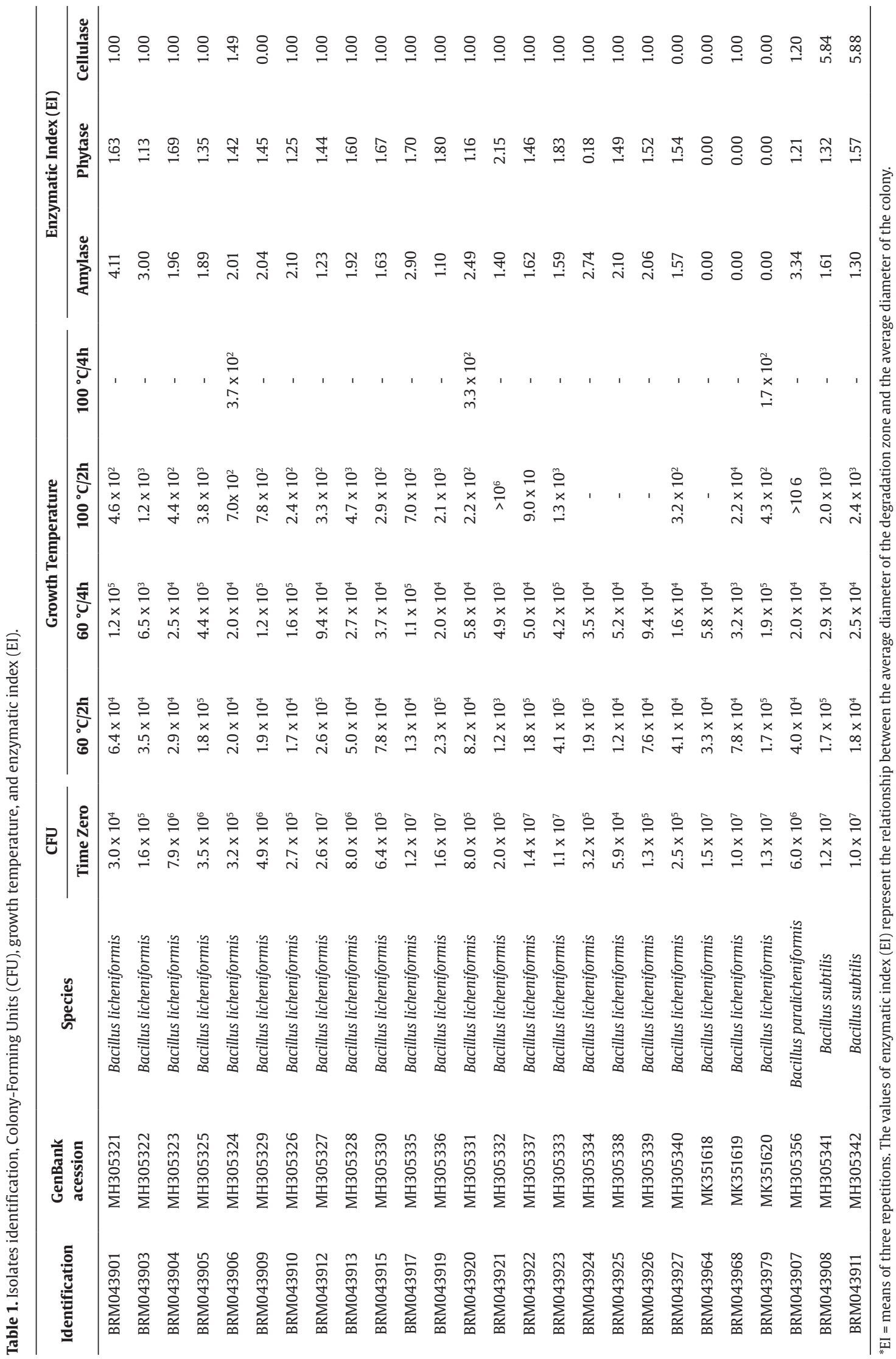




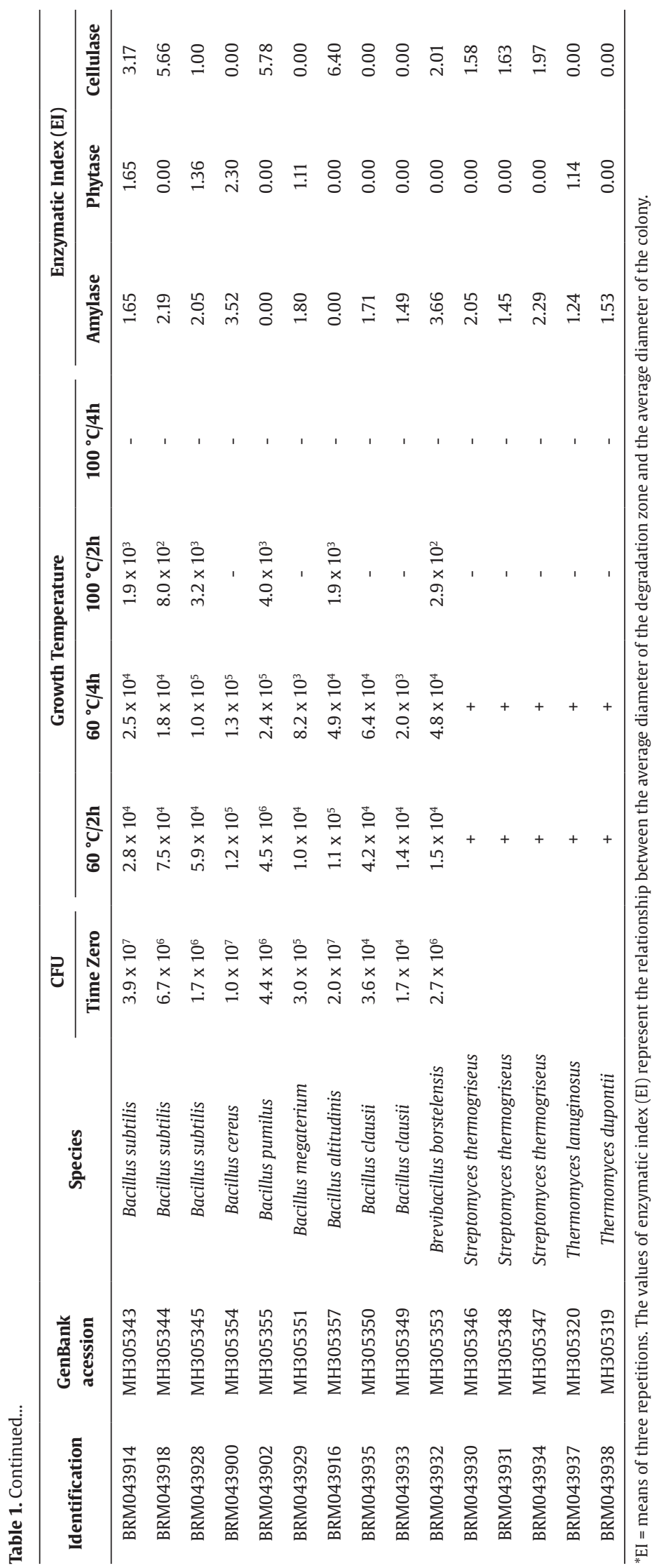




\subsection{Evaluation of heat shock resistance (temperature above $50{ }^{\circ} \mathrm{C}$ )}

Of the 85 bacteria tested for heat stress, 75 survived at $60{ }^{\circ} \mathrm{C}$ for two hours, and of these, 72 survived at $60^{\circ} \mathrm{C}$ for four hours. Twenty-eight resisted to $100^{\circ} \mathrm{C}$ for two hours from the last group, and three survived to incubation at $100{ }^{\circ} \mathrm{C}$ for four hours. Among the twenty actinomycetes isolates, eight were resistant to incubation at $60^{\circ} \mathrm{C}$ for two and four hours, and none survived at $100^{\circ} \mathrm{C}$. The two fungal isolates were unable to grow at $60{ }^{\circ} \mathrm{C}$ or $100{ }^{\circ} \mathrm{C}$. After the thermal stress, forty-one different morphotypes, 36 of bacteria, three actinomycetes were identified, and together with the two fungal isolates, they were selected for molecular identification.

\subsection{Molecular identification}

The 16S rDNA sequencing results of the 41 isolates confirmed the morphological identification of the thirty-six bacteria, three actinomycetes, and two fungi. Among the 36 bacterial isolates, 35 belonged to the genus Bacillus, with the species $B$. licheniformis predominating (23 isolates), followed by $B$. subtillis (5 isolates), B. clausii (2 isolates), and one of each of B. cereus, B. paralicheniformis, B. pumilus, $B$. megaterium $B$. altitudinis. One bacterial isolate was Brevibacillus bortolensis. The three isolates of Actinomycetes were identified as Streptomyces thermogriseus, and the two fungi were Thermomyces lanuginosus and T. dupontii. The isolates with their respective GenBank accession numbers are shown in Table 1.

\subsection{Evaluation of enzyme activity}

Of the 41 isolates tested for enzyme production, using the criterion for Enzyme Index (EI) values $\geq 2$, Seventeen were amylase producers, three phytase, and seven cellulose producers. Of these, two strains BRM043901 and BRM043903 of Bacillus licheniformis, and one strain of B. paralicheniformis (BRM043907) were heat shock resistant to the treatment at $100^{\circ} \mathrm{C} / 2 \mathrm{~h}$, the EI for amylase were equal to $4.11,3.00$, and 3.34 , respectively (Table 1 ). For amylase, two other strains of $B$. licheniformis (BRM043906 and BRM043920), resistant to $100^{\circ} \mathrm{C} / 4 \mathrm{~h}$, obtained an EI equal to 2.01 and 2.49, respectively. The highest EI value for phytase was 2.30 for the strain BRM043900 of B. cereus resistant to the treatment at $60{ }^{\circ} \mathrm{C} / 4 \mathrm{~h}$. For cellulase, the group of isolates resistant to $60^{\circ} \mathrm{C} / 2 \mathrm{~h}$ or $60^{\circ} \mathrm{C} / 4 \mathrm{~h}$, and $100^{\circ} \mathrm{C} / 2 \mathrm{~h}$, the highest EI values $\geq 5.0$ were observed for $B$. subitilis isolates BRM043908 (EI=5.84) and BRM043911 (EI=5.88), B. pumilus BRM043902 (EI=5.66), and B. altitudinis BRM043916 (EI=6.40). Two actinomycetes (BRM043930 and BRM043934) showed EI values of 2.05 and 2.29 for amylase production, respectively. The two fungi (BRM043937 and BRM043938) were not efficient in enzymes production with EI values varying from 0.0 to 1.53 (Table 1 ).

\section{Discussion}

In our study, the microorganisms were isolated from aerobic organic composting of mixed vegetables waste (co-composting). The composting system is a natural breakdown of dead organic matter made by a continuous succession of microbial communities and small saprophyte organisms (Insam and Bertoldi, 2007; Irvine et al., 2010; Song et al., 2014). The size and complexity of a transient microbial community in the composting vary according to biological, chemical, and physical factors like moisture content, temperature, $\mathrm{pH}$, surface area, particle size, the volume of the composting mass, and aeration (Zakarya et al., 2018; Meng et al., 2019; Piazza et al., 2020). As the organic matter decay is based on exothermic reactions, a natural rise in temperature occurs during the composting process. Thus, the temperature is a critical limiting variable for the evolution of a composting since the succession of the microbial community and their representativeness in the degradation phases are highly dependent on this parameter (Oliveira et al., 2004; Haruta et al., 2005; Fujino et al., 2005; Insam and Bertoldi, 2007; Rebollido et al., 2008; Irvine et al., 2010; Heck et al., 2013; Castro-Fernández et al., 2018). The conventional composting processes typically comprise four major microbiological stages concerning temperature: mesophilic, thermophilic, cooling, and maturation (Rebollido et al., 2008; Irvine et al., 2010). During the process, the microbial community changes, and the final product is the compost (Irvine et al., 2010). When composting temperature exceeds $40^{\circ} \mathrm{C}$, the thermophilic microorganisms start to predominate in composting and rapidly accelerate the organic matter decomposition (Insam and Bertoldi, 2007; Ribeiro et al., 2017). As the temperature increases above to $65{ }^{\circ} \mathrm{C}$, most mesophilic microorganisms are eliminated, and those thermoresistant or thermophilic turn predominant. Thus, as the temperature rises and falls, different microbial species become more or less active (Partanen et al., 2010; Neher et al., 2013). When the temperature drops, the most thermophiles die off, and the compost enters into the mature stage. Mesophiles, which has been working in a reduced capacity around the colder area of the decomposing, will become more active (Ansari and Hanief, 2015). In our study, the average temperature of the $\mathrm{C} 1$ sample was $51.9^{\circ} \mathrm{C}$, with counts of $4.0 \times 10^{7} \mathrm{CFU} . \mathrm{g}^{-1}$ for bacteria, $2.0 \times 10^{7} \mathrm{CFU}^{-1}$ for actinomycetes, and $1.1 \times 10^{3} \mathrm{CFU}^{-1}$ for fungi. The sample $\mathrm{C} 2$ showed an average temperature of $63^{\circ} \mathrm{C}$ and counts of $5.8 \times 10^{6} \mathrm{CFU}^{-1} \mathrm{~g}^{-1}, 1.8 \times 10^{6} \mathrm{CFU}^{-1}{ }^{-1}$, and $1.7 \times 10^{5} \mathrm{CFU}^{-1}$ for bacteria, actinomycetes, and fungi, respectively. In the sample $\mathrm{C} 3$, after more than 12 months of the initial composting process, the temperature was $25 \pm 1^{\circ} \mathrm{C}$. We were interested primarily in isolating thermophilic microorganisms; thus, the samples were collected at the thermophilic stage ( $\mathrm{C} 1$ at $51 \pm 1^{\circ} \mathrm{C}$, and $\mathrm{C} 2$ at $63 \pm 1{ }^{\circ} \mathrm{C}$ ) and maturation ( $\mathrm{C} 3$ at $25 \pm 1^{\circ} \mathrm{C}$ ). In these two stages, the composting mass was colonized at a significant proportion by bacteria (79.4\%), followed by actinomycetes (18.7\%) and in lower numbers by fungi (1.9\%).

The molecular characterization of the thermoresistant isolates showed that $88 \%$ (36 isolates) were Bacillus spp., and in this group, $64 \%$ were $B$. licheniformis. The other major group was B. subtilis (14\%) with five isolates. This result confirms previous studies describing that Bacillus spp. is the primary group of microorganisms frequently isolated from different compost masses (Souza and Martins, 2001; Zainudin et al., 2013; López-González et al., 2014; 
López-González, et al., 2015; Chin et al., 2017; Ribeiro et al., 2017). The high frequency of thermophilic Bacillus spp. in composting may be associated with its ability to form resistant spores under environmental conditions that kill most other organisms. Thus, the ability to form spore confer an adaptive advantage to Bacillus, and several strains from composting produce hydrolytic enzymes, biosurfactants, antibiotics, and plant growth promoters (Yakimov et al., 1995; Dhanarajan et al., 2017; Jeong et al., 2017; Hsu et al., 2018; Sonune and Garode, 2018). Some thermophilic bacteria show a high metabolic capacity to degrade recalcitrant substances such as lignin, which is particularly interesting for industrial applications (Charbonneau et al., 2012; Gautam et al., 2012; Bhattacharya and Pletschke, 2014; Gonzalo et al., 2016; Ahirwar et al., 2017; Siu-Rodas et al., 2018).

Although all composting has many common characteristics, such as mesophilic, thermophilic, and maturity phases, other peculiar attributes are unique (Partanen et al., 2010). Microbial groups are frequently detected in moderate or high counts at all or many composting stages (Ribeiro et al., 2017). Galitskaya et al. (2017), using the pyrosequencing technique to study the fungal and bacterial successions in co-composting of organic wastes, found that the number of $16 \mathrm{~S}$ bacterial copies $\left(\sim 10^{6}\right)$ were superior to fungi ITS $\left(\sim 10^{5}\right)$ in the initial stage of the process. In the present study, five species were isolated at all sampling times, and 36 out of 41 were Firmicutes. Whereas some species were present at almost every sampling time, i.e., Bacillus licheniformis, most isolates were found at low frequency or, in one or two samples (actinomyces and fungi).

$B$. licheniformis has excellent potential for practical and biotechnological processes. The sequencing data of the complete genome of $B$. licheniformis revealed 82 genes encoding hydrolytic enzymes for accelerating the composting hydrolysis process polysaccharides, proteins, lipids, and other compounds for biotechnological uses (Rey et al., 2004). The comparison between B. licheniformis and $B$. subitilis genomes identified 27 extracellular proteins in B. licheniformis that were absent in B. subitilis (Rey et al., 2004). Also, in the fungi group, Janusz et al. (2017) found that different wood degradation strategies possibly correlate to the number of genes coded for secretory enzymes. Several strains of thermoresistant Bacillus licheniformis isolated from composting produce hydrolytic enzymes, biosurfactant compounds for environmental decontamination, antimicrobial activity, and plant growth (Yakimov et al., 1995; Dhanarajan et al., 2017; Hsu et al., 2018; Sonune and Garode, 2018). Thermophilic strains of $B$. licheniformis produce a soluble biopolymer that enhances the mobilization and solubilization of oil contaminants in the soil (Dhanarajan et al., 2017). Hsu et al. (2018) used the probiotic properties of a $B$. licheniformis strain to remove up to $70 \%$ of the mycotoxin zearalenone contamination in cereal grains. Benzoic acid from Bacillus licheniformis strain MH48 was useful for controlling various fungal plant pathogens (Jeong et al., 2017).

At the end of the thermophilic stage, the bacterial and fungal species composition changed significantly, while their relative abundance decreased. During the later composting stages, the dominant bacterial and fungal communities remained active, but their relative abundance decreased. In our study, the bacterial community members were very stable and isolated at high frequency in all treatments, while the frequency of fungi was very low and isolated only in the thermophilic stage. These results show that the dynamic of microbial communities in composting may vary due to the high complexity of many biological and environmental parameters, such as the initial microbial population, temperature, $\mathrm{pH}$, and moisture interacting in a specific way (Chandna et al., 2013). According to the study by Villar et al. (2016), the nature of the starting material determined the microbial dynamics in composting systems. In our study, the dynamics of the microbial community in the composting were not similar. In our study, the microbial communities underwent significant changes from the first to second thermophilic phase ( $\mathrm{C} 1$ to $\mathrm{C2}$ ) during the 33rd to the 60th-day interval. The bacterial counting gradually decreases over the three stages $\left(10^{7}, 10^{6}\right.$, and $\left.10^{5}\right)$, while actinomycetes and fungi increased during the second thermophilic phase and became countless after the composting maturation. In a recent study, Galitskaya et al. (2017) found that although the dominating taxa of bacterial and fungal communities remained during the later composting stages, their relative abundance decreased.

Biologically active enzymes have been obtained from plants, animals, and microorganisms. However, high amounts of microbial enzymes stable at various extreme conditions are easily isolated in fast, low-cost production and show high reliability for industrial processes and applications (Gopinath et al., 2017). Microbial enzymes involved in the composting process as cellulases, amylase, $\beta$-glucosidases, proteases, ureases, phytase, phosphatases, and arylsulphatases are potential candidates for biotechnological applications. These enzymes are active in cellulose depolymerization, hydrolysis of amide and glycosidic bonds, nitrogen mineralization, and release of phosphate and sulfate groups from organic compounds (Bernardi et al., 2018). In this study, we tested three enzymes production by microorganisms isolated from organic composting: amylase, phytase, and cellulase.

Amylases are necessary enzymes employed in the food industry to hydrolyze starch molecules into polymers composed of glucose units (Berry and Paterson, 1990). The $\alpha$-amylase is the most critical enzyme to initiate the starch hydrolysis reaction (Windish and Mhatre, 1965). Microbial amylases have been primarily used for the starch breakdown in the industrial sectors. Baratto et al. (2011) observed that $\alpha$-amylase from fungal origin decrease their activity rapidly at temperatures above $50{ }^{\circ} \mathrm{C}$, while in bacterial, the enzyme has high stability to elevated temperatures. In a study, Wu et al. (2018) demonstrated the thermo resistance of an acidophilic $\alpha$-amylase produced by B. licheniformis isolated from hot springs (Wu et al., 2018). In our study, seventeen isolates among B. licheniformis, B. subtilis, B. cereus, Bacillus paralicheniformis, Brevibacillus borstelensis, and Streptomyces thermogriseus are promising for use in the food and starch processing industries.

Phytate (inositol hexaphosphate), in the salt form of phytic acid, represents the primary storage form 
of phosphorus (P) and inositol in many plant tissues (Cosgrove, 1980; Ravindran et al., 1994). Phytate strongly interacts with divalent minerals in the soil, such as magnesium, calcium, zinc, and iron, and becomes highly unavailable as a P source for microorganisms, plants, and animals (George et al., 2007; Menezes-Blackburn et al., 2016). Therefore, phytate is considered an anti-nutritive compound for non-ruminant animals since they lack the enzyme phytase necessary to solubilize the stored $\mathrm{P}$ in the phytate compound (Dersjant-Li et al., 2015). Hence, the undigested phytate negatively affects the absorption of minerals and other nutrients, inhibiting certain digestive enzymes, and binding to carbohydrates and vital proteins required for energy and growth (Hallberg et al., 1989; Greger, 1999; Bohn et al., 2004; Phillippy, 2006; Selle et al., 2000; Amina et al., 2017). For this reason, several food processing and preparation methods use the enzyme phytase to reduce the phytate content of cereals and legumes (Jatuwong et al., 2020). Microbial phytase has been considered the most promising enzyme in food processing and feed pellet manufacturing industries specialized in birds and non-ruminant animals (Dersjant-Li et al., 2015; Amina et al., 2017). However, phytase and other enzymes are sensitive to high temperatures, $80^{\circ} \mathrm{C}$ or more, applied during the pelleting process. Thermostable phytase may be a suitable candidate for feed processing and supplements (Konietzny and Greiner, 2004). Thus, identifying novel thermotolerant phytase isoforms can be of significance in food and feed processing industries.

It has been shown that phytate-utilizing bacteria may improve P-bioavailability in composting and $\mathrm{P}$ acquisition by plants (Richardson et al., 2005; Fuentes et al., 2006). Therefore, studies on composting microbial community and its phytate degradation ability might contribute to ameliorate the compost quality and provide new strains for biotechnological processes. Microbial inoculants have been studied as a strategic tool to enhance the Pi-availability in organic wastes and plants. Menezes-Blackburn et al. (2016) demonstrated that Pi-availability in cattle manure was increased by inoculating phytase-producing bacteria in the composting of agricultural wastes. The authors concluded that phytase-producing bacteria inoculation represents an attractive strategy to increase Pi-availability in agricultural wastes with potential applications as organic fertilizers in crops and pastures (Menezes-Blackburn et al., 2016). Microbial phytase activity in soil has been more frequently detected in fungi followed by bacteria, and most of the soil bacteria detected to possess phytase activity belong to the Gammaproteobacterial group (Amina et al., 2017). In our study, only two bacterial strains from Firmicutes showed $\mathrm{EI} \geq 2$.0. The result, together with the fact that none of the fungi isolates was efficient in phytase production, highlights that thermotolerant phytase-efficient microorganisms at the time of implementing future composting systems may improve the quality of the final compost.

Cellulose, hemicelluloses, and lignin are essential components of the primary plant cell wall and the most abundant organic polymer on Earth. Cellulose has a broad use in industry to produce paper and various derivative products such as cellophane, rayon, fibers, and other miscellaneous products. Cellulose contains large reservoirs of energy that provide real potential for conversion into biofuels. Conversion of cellulose into biofuel, such as cellulosic ethanol, is under development as a renewable fuel since 1898 (Harris et al., 1945; Mosier et al., 2005). Cellulase is an important enzyme involved in the composting process. Cellulase works at temperatures typically above $50{ }^{\circ} \mathrm{C}$ with the temperature optima at $70{ }^{\circ} \mathrm{C}$. Mayende et al. (2006) isolated thermophilic bacteria from organic composting capable of producing thermophilic cellulases at $60^{\circ} \mathrm{C}$ and $70{ }^{\circ} \mathrm{C}$ and extremely thermophilic at $80^{\circ} \mathrm{C}$ with potential for application in industrial biotechnology. Rocha (2010) isolated a thermoresistant strain of Bacillus cereus from hot springs in the Brazilian state of Goiás, and the selected strain is grown up at $50^{\circ} \mathrm{C}$ and showed high cellulolytic activity. In the present study, Bacillus subtilis, Bacillus pumilus, and Bacillus altitudinis were high producers of cellulase with EI values above to 5.0., thus they have a high potential application in biotechnological processes.

\section{Conclusions}

The present study's main contribution is the isolation and characterization of new thermophilic and thermotolerant isolates from composting that may be tested as inoculant activators to accelerate the composting processes in organo-mineral fertilizer production; and applications in many biotechnological processes requiring high temperatures. The bacterial group was more resistant to thermal stress than fungi and actinomycetes, and more efficient in producing the hydrolytic enzymes amylase, phytase, and cellulase. Spore-forming bacteria from firmicutes are the most frequent microbial group in composting mass. Thermoresistant $B$. licheniformis strains, resistant to treatment at $100{ }^{\circ} \mathrm{C}$ for $4 \mathrm{~h}$, were more efficient in producing amylase. The thermoresistant Bacillus stratosphericus ( $100^{\circ} \mathrm{C}$ for $2 \mathrm{~h}$ ) showed the highest EI value for cellulase $(E I=6.4)$. The present study's main contribution is the isolation and characterization of new thermophilic and thermotolerant isolates from composting that may be tested as inoculant activators to accelerate the composting processes in organo-mineral fertilizer production; and applications in many biotechnological processes requiring high temperatures.

\section{Acknowledgements}

The authors would like to thank the Centro Universitário de Sete Lagoas, UNIFEMM, and Embrapa Milho e Sorgo, for financial support.

\section{References}

ABREU, C.S., FIGUEIREDO, J.E., OLIVEIRA, C.A., SANTOS, V.L., GOMES, E.A., RIBEIRO, V.P., BARROS, B.A., LANA, U.G.P. and MARRIEL, I.E., 2017. Maize endophytic bacteria as mineral phosphate solubilizers. Genetics and Molecular Research, vol. 16, no. 1. http://dx.doi.org/10.4238/gmr16019294. PMid:28218783.

AHIRWAR, S., SONI, H., PRAJAPATI, B.P. and KANGO, N., 2017. Isolation and screening of thermophilic and thermotolerant fungi for 
production of hemicellulasesfrom heated environments. Mycology, vol. 8, no. 3, pp. 125-134. http://dx.doi.org/10.1080 /21501203.2017.1337657.

AMINA, A., SAVITA, P.D., YALLAPPA, M., NIVETHA, N. and SURVANA, V.C., 2017. Phytate solubilizing microorganisms and enzyme phytase to combat nutritional problems in cereal-based foods. Journal of Bacteriology and Mycology, vol. 4, no. 3, pp. 86-89. http://dx.doi.org/10.15406/jbmoa.2017.04.00093.

ANSARI, A. and HANIEF, A., 2015. Microbial degradation of organic waste through vermicomposting. International Journal of Sustainable Agricultural Research, vol. 2, no. 2, pp. 45-54. http:// dx.doi.org/10.18488/journal.70/2015.2.2/70.2.45.54.

ASSOCIAÇÃO NACIONAL PARA DIFUSÃO DE ADUBOS - ANDA, 2016. Setor de Fertilizantes. Anuário Estatístico. São Paulo: ANDA.

BARATTO, C.M., SALAMONI, S.P., COSTA, R., OLIVEIRA, C.B. and LOCATELLI, G.O. 2011. Seleção de microrganismos produtores de enzimas hidrolíticas isolados da região do meio oeste de Santa Catarina, Brasil. Evidência, vol. 11, no. 2, pp. 15-28.

BEEVER, R.E. and BOLLARD, E.G., 1970. The nature of the stimulation of fungal growth by potato extract. Journal of General Microbiology, vol. 60, no. 2, pp. 273-279. http://dx.doi. org/10.1099/00221287-60-2-273.

BERNARDI, F.H., COSTA, M.S.S.M., COSTA, L.A.M., DAMACENO, F.M. and CHIARELOTTO, M., 2018. Microbiological activity during the composting of wastes from broiler productive chain. Engenharia Agrícola, vol. 38, no. 5, pp. 741-750. http://dx.doi. org/10.1590/1809-4430-eng.agric.v38n5p741-750/2018.

BERRY, D.R. and PATERSON, A., 1990. Enzymes in food industry. In: C.J. SUCKLING, ed. Enzyme Chemistry. Dordrecht: Springer, pp. 306-351. http://dx.doi.org/10.1007/978-94-009-1832-0_8.

BHARDWAJ, D., ANSARI, M.W., SAHOO, R.K. and TUTEJA, N., 2014. Biofertilizers function as key player in sustainable agriculture by improving soil fertility, plant tolerance and crop productivity. Microbial Cell Factories, vol. 13, no. 1, pp. 66. http://dx.doi. org/10.1186/1475-2859-13-66. PMid:24885352.

BHATT, M.K., LABANYA, R. and JOSHI, H.C., 2019. Influence of longterm chemical fertilizers and organic manures on soil fertility: A review. Universal Journal of Agricultural Research, vol. 7, no. 5, pp. 177-188. http://dx.doi.org/10.13189/ujar.2019.070502.

BHATTACHARYA, A. and PLETSCHKE, B. 2014. Thermophilic Bacilli and their enzymes in composting. In: D. MAHESHWARI, ed. Composting for Sustainable Agriculture. Sustainable development and biodiversity. Cham: Springer, vol. 3, pp. 103-124. http:// dx.doi.org/10.1007/978-3-319-08004-8_6.

BOHN, T., DAVIDSSON, L., WALCZYK, T. and HURRELL, R.F., 2004. Phytic acid added to white-wheat bread inhibits fractional apparent magnesium absorption in humans. The American Journal of Clinical Nutrition, vol. 79, no. 3, pp. 418-423. http:// dx.doi.org/10.1093/ajen/79.3.418. PMid:14985216.

BRASILAGRO. 2020. [viewed 14 August 2020] Importação de fertilizantes pelo Brasil é recorde em 2019 [online]. Available from: https://www.brasilagro.com.br/conteudo/importacaode-fertilizantes-pelo-brasil-e-recorde-em-2019.html.

CAMENZIND, T., HÄTTENSCHWILER, S., TRESEDER, K.K., LEHMANN, A. and RILLIG, M.C., 2018. Nutrient limitation of soil microbial processes in tropical forests. Ecological Monographs, vol. 88, no. 1, pp. 4-21. http://dx.doi.org/10.1002/ecm.1279.

CASTRO-FERNÁNDEZ,J.J., SERRATO-GONZÁLEZ, A., RUIZ-MONTOYA, M. and DÍAZ, M.J., 2018. Influence of controllable variables on the composting process, kinetic, and maturity of Stevia rebaudiana residues. International Journal of Recycling of Organic Waste in Agriculture, vol. 7, no. 4, pp. 277-286. http://dx.doi. org/10.1007/s40093-018-0214-X.
CELLA, D. and ROSS, M.C.L., 2010. Análise do mercado de fertilizantes no Brasil. Interface Tecnológica, vol. 7, no. 1, pp. 41-50.

CHANDNA, P., NAIN, L., SINGH, S. and KUHAD, R.C., 2013. Assessment of bacterial diversity during composting of agricultural byproducts. BMC Microbiology, vol. 13, no. 1, pp. 99. http:// dx.doi.org/10.1186/1471-2180-13-99. PMid:23651653.

CHARBONNEAU, D.M., MEDDEB-MOUELHI, F., BOISSINOT, M., SIROIS, M. and BEAUREGARD, M., 2012. Identification of thermophilic bacterial strains producing thermotolerant hydrolytic enzymes from manure compost. Indian Journal of Microbiology, vol. 52, no. 1, pp. 41-47. http://dx.doi.org/10.1007/s12088-011-0156-8. PMid:23448754.

CHIN, C.F.S., FURUYA, Y., ZAINUDIN, M.H.M., RAMLI, N., HASSAN, M.A., TASHIRO, Y. and SAKAI, K., 2017. Novel multifunctional plant growth-promoting bacteria in co-compost of palm oil industry waste. Journal of Bioscience and Bioengineering, vol. 124, no. 5, pp. 506-513. http://dx.doi.org/10.1016/j.jbiosc.2017.05.016. PMid:28736147.

CORREA, J.C., GROHSKOPF, M.A., REBELLATO, A., RIGO, A.Z. and COLDEBELLA, A., 2018. Adubação de milho de alto rendimento com cama de aves tendo como critério o nitrogênio. Pesquisa Agropecuária Brasileira, vol.53, no. 3, pp. 342-350. http://dx.doi. org/10.1590/s0100-204x2018000300009.

COSGROVE, D.J., 1980. The determination of myo-inositol hexakisphosphate (phytate). Journal of the Science of Food and Agriculture, vol. 31, no. 12, pp. 1253-1256. http://dx.doi. org/10.1002/jsfa.2740311206.

COUNTS, J.A., ZELDES, B.M., LEE, L.L., STRAUB, C.T., ADAMS, M.W.W. and KELLY, R.M., 2017. Physiological, metabolic and biotechnological features of extremely thermophilic microorganisms. Wiley Interdisciplinary Reviews. Systems Biology and Medicine, vol. 9, no. 3, pp. e1377. http://dx.doi.org/10.1002/ wsbm.1377. PMid:28206708.

DERSJANT-LI, Y., AWATI, A., SCHULZE, H. and PARTRIDGE, G., 2015. Phytase in non-ruminant animal nutrition: a critical review on phytase activities in the gastrointestinal tract and influencing factors. Journal of the Science of Food and Agriculture, vol. 95, no. 5, pp. 878-896. http://dx.doi.org/10.1002/jsfa.6998. PMid:25382707.

DHANARAJAN, G., RANGARAJAN, V., BANDI, C., DIXIT, A., DAS, S., ALE, K. and SEN, R., 2017. Biosurfactant-biopolymer driven microbial enhanced oil recovery (MEOR) and its optimization by an ANN-GA hybrid technique. Journal of Biotechnology, vol. 256, pp. 46-56. http://dx.doi.org/10.1016/j.jbiotec.2017.05.007. PMid:28499818.

DOYLE, J.J. and DOYLE, J.L., 1990. Isolation of plant DNA from fresh tissue. Focus, vol. 12, pp. 13-15.

ECONOMIC COMMISSION FOR LATIN AMERICA AND THE CARIBBEAN - ECLAC, 2019 [viewed 22 March 2021]. Social Panorama of Latin America [online]. Santiago: United Nations. Available from: https://repositorio.cepal.org/bitstream/handle/11362/44989/ S1901132_en.pdf? sequence $=1$ \&isAllowed $=\mathrm{y}$.

EZE, U.N., OKONJI, R.E., IBRAHEEM, O. and SHONUKAN, O.O., 2011. Isolation and characterization of a bacterial thermostable protease from poultry dung. Ife Journal of Science, vol. 13, no. 2, pp. 289-297.

FERREIRA, D.F., 2008. SISVAR: um programa para análises e ensino de estatística. Revista Científica Symposium, vol. 6, no. 2, pp. 36-41.

FUENTES, B., BOLAN, N., NAIDU, R. and MORA, L.M., 2006. Phosphorus in organic waste-soil systems. Journal of Soil Science and Plant Nutrition, vol. 6, no. 2, pp. 64-83. http://dx.doi.org/10.4067/ S0718-27912006000200006. 
FUJINO, J., MORITA, A., MATSUOKA, Y. and SAWAYAMA, S., 2005. Vision for utilization of livestock residue as bioenergy resource in Japan. Biomass and Bioenergy, vol. 29, no. 5, pp. 367-374. http://dx.doi.org/10.1016/j.biombioe.2004.06.017.

GALEMBECK, F., GALEMBECK, A. and SANTOS, L.P., 2019. NPK: essentials for sustainability. Quimica Nova, vol. 42, no. 10, pp. 1199-1207. http://dx.doi.org/10.21577/0100-4042.20170441.

GALITSKAYA, P., BIKTASHEVA, L., SAVELIEV, A., GRIGORYEVA, T., BOULYGINA, E. and SELIVANOVSKAYA, S., 2017. Fungal and bacterial successions in the process of co-composting of organic wastes as revealed by 454 pyrosequencing. PLoS One, vol. 12, no. 10, pp. e0186051. http://dx.doi.org/10.1371/journal. pone.0186051. PMid:29059245.

GAUTAM, S.P., BUNDELA, P.S., PANDEY, A.K., JAMALUDDIN., AWASTHI, M.K. and SARSAIYA, S, 2012. Diversity of cellulolytic microbes and the biodegradation of municipal solid waste by a potential strain. International Journal of Microbiology, vol. 2012, pp. 325907. http://dx.doi.org/10.1155/2012/325907. PMid:22518141.

GEORGE, T., QUIQUAMPOIX, H., SIMPSON, R. and RICHARDSON, A. 2007. Interactions between phytases and Soil constituents: Implications for the Hydrolysis of Inositol Phosphates. In: B. TURNER, A. RICHARDSON, E. MULLANEY, ed. Inositol Phosphates: Linking agriculture and the environment. Oxfordshire: CABI, pp. 221-241 http://dx.doi.org/10.1079/9781845931520.0221.

GONZALO, G., COLPA, D.I., HABIB, M.H. and FRAAIJE, M.W., 2016. Bacterial enzymes involved in lignin degradation. Journal of Biotechnology, vol. 236, pp. 110-119. http://dx.doi.org/10.1016/j. jbiotec.2016.08.011. PMid:27544286.

GOPINATH, S.C.B., ANBU, P., ARSHAD, M.K.M., LAKSHMIPRIYA, T., VOON, C.H., HASHIM, U. and CHINNI, S.V., 2017. Biotechnological processes in microbial amylase production. BioMed Research International, vol. 2017, pp. 1272193. http://dx.doi. org/10.1155/2017/1272193. PMid:28280725.

GOU, C., WANG, Y., ZHANG, X., LOU, Y. and GAO, Y., 2017. Inoculation with a psychrotrophic-thermophilic complex microbial agent accelerates onset and promotes maturity of dairy manure-rice straw composting under cold climate conditions. Bioresource Technology, vol. 243, pp. 339-346. http://dx.doi.org/10.1016/j. biortech.2017.06.097. PMid:28683387.

GREGER, J.L., 1999. Nondigestible Carbohydrates and Mineral Bioavailability. The Journal of Nutrition, vol. 129, no. 7, (suppl.), pp. 1434S-1435S. http://dx.doi.org/10.1093/jn/129.7.1434S. PMid:10395614.

HALLBERG, L., BRUNE, M. and ROSSANDER, L., 1989. Iron-absorption in man: ascorbic-acid and dose-dependent inhibition by phytate. The American Journal of Clinical Nutrition, vol. 49, no. 1, pp. 140 144. http://dx.doi.org/10.1093/ajcn/49.1.140. PMid:2911999.

HARRIS, E.E., BEGLINGER, E., HAJNY, G.J. and SHERRARD, E.C., 1945. Hydrolysis of wood: Treatment with Sulfuric Acid in a stationary digester. Industrial \& Engineering Chemistry, vol. 37, no. 1, pp. 12-23. http://dx.doi.org/10.1021/ie50421a005.

HARTMANN, R.F., WOLTER, S.J., KROGER, B., SCHULTZE, S., SPECHT, T. and ERDMANN, V.A., 1989. Does thermos represent another deep eubacteria branching? Systematic and Applied Microbiology, vol. 11, n. 3, pp. 243-249. https://doi.org/10.1016/S07232020(89)80020-7.

HARUTA, S., NAKAYAMA, T., NAKAMURA, K., HEMMI, H., ISHII, M., IGARASHI, Y. and NISHINO, T., 2005. Microbial diversity in biodegradation and reutilization processes of garbage. Journal of Bioscience and Bioengineering, vol. 99, no. 1, pp. 1-11. http:// dx.doi.org/10.1263/jbb.99.1. PMid:16233746.

HECK, K., DE MARCO, E.G., HAHN, A.B.B., KLUGE, M., SPILKI, F.R. and VAN DER SAND, S.T., 2013. Temperatura de degradação de resíduos em processo de compostagem e qualidade microbiológica do composto final. Revista Brasileira de Engenharia Agrícola e Ambiental, vol. 17, no. 1, pp. 54-59. http://dx.doi. org/10.1590/S1415-43662013000100008.

HIGASHIKAWA, F.S., SILVA, C.A. and BETTIOL, W., 2010. Chemical and physical properties of organic residues. Revista Brasileira de Ciência do Solo, vol. 34, no. 5, pp. 1743-1752. http://dx.doi. org/10.1590/S0100-06832010000500026.

HSU, T.C., YI, P.J., LEE, T.Y. and LIU, J.R., 2018. Probiotic characteristics and zearalenone-removal ability of a Bacillus licheniformis strain. PLoS One, vol. 13, no. 4, pp. e0194866. http://dx.doi.org/10.1371/ journal.pone.0194866. PMid:29641608.

HUANG, J., XU, C.C., RIDOUTT, B.G., WANG, X. and REN, P., 2017. Nitrogen and phosphorus losses and eutrophication potential associated with fertilizer application to cropland in China. Journal of Cleaner Production, vol. 159, pp. 171-179. http:// dx.doi.org/10.1016/j.jclepro.2017.05.008.

INSAM, H. and BERTOLDI, M. 2007. Microbiology of the composting process. In: L.F. DIAZ, M. BERTOLDI, W. BIDLINGMAIER and E. STENTFORD, ed. Compost science and technology. Amsterdam: Elsevier, vol. 8, pp. 25-48. http://dx.doi.org/10.1016/S14787482(07)80006-6.

IRVINE, G., LAMONT, E.R. and ANTIZAR-LADISLAO, B., 2010. Energy from Waste: reuse of compost heat as a source of renewable energy. International Journal of Chemical Engineering, vol. 2010, pp. 627930. http://dx.doi.org/10.1155/2010/627930.

JANUSZ, G., PAWLIK, A., SULEJ, J., SWIDERSKA-BUREK, U., JAROSZWILKOLAZKA, A. and PASZCZYNSKI, A., 2017. Lignin degradation: microorganisms, enzymes involved, genomes analysis and evolution. FEMS Microbiology Reviews, vol. 41, no. 6, pp. 941962. http://dx.doi.org/10.1093/femsre/fux049. PMid:29088355.

JARVIE, H.P., SMITH, D.R., NORTON, L.R., EDWARDS, F.K., BOWES, M.J., KING, S.M., SCARLETT, P., DAVIES, S., DILS, R.M. and BACHILLERJARENO, N., 2018. Phosphorus and nitrogen limitation and impairment of headwater streams relative to rivers in Great Britain: A national perspective on eutrophication. The Science of the Total Environment, vol. 621, pp. 849-862. http://dx.doi. org/10.1016/j.scitotenv.2017.11.128. PMid:29216593.

JATUWONG, K., SUWANNARACH, N., KUMLA, J., PENKHRUE, W., KAKUMYAN, P. and LUMYONG, S., 2020. Bioprocess for production, characteristics, and biotechnological applications of fungal phytases. Frontiers in Microbiology, vol. 11, pp. 188. http://dx.doi.org/10.3389/fmicb.2020.00188. PMid:32117182.

JEONG, M.H., LEE, Y.S., CHO, J.Y., AHN, Y.S., MOON, J.H., HYUN, H.N., CHA, G.S. and KIM, K.Y., 2017. Isolation and characterization of metabolites from Bacillus licheniformis MH48 with antifungal activity against plant pathogens. Microbial Pathogenesis, vol. 110, pp. 645-653. http://dx.doi.org/10.1016/j.micpath.2017.07.027. PMid:28733027.

KONIETZNY, U. and GREINER, R., 2004. Bacterial phytase: potential application, in vivo function and regulation of its synthesis. Brazilian Journal of Microbiology, vol. 35, no. 1-2, pp. 11-18. http://dx.doi.org/10.1590/S1517-83822004000100002.

LÓPEZ-GONZÁLEZ, D., FERNANDEZ-LOPEZ, M., VALVERDE, J.L. and SANCHEZ-SILVA, L., 2014. Kinetic analysis and thermal characterization of the microalgae combustion process by thermal analysis coupled to mass spectrometry. Applied Energy, vol. 114, pp. 227-237. http://dx.doi.org/10.1016/j. apenergy.2013.09.055.

LÓPEZ-GONZÁLEZ, J.A., SUÁREZ-ESTRELLA, F., VARGAS-GARCÍA, M.C., LÓPEZ, M.J., JURADO, M.M. and MORENO, J., 2015. Dynamics of bacterial microbiota during lignocellulosic waste composting: studies upon its structure, functionality and biodiversity. 
Bioresource Technology, vol. 175, pp. 406-416. http://dx.doi. org/10.1016/j.biortech.2014.10.123. PMid:25459849.

MACEDO, E.F.S. and NISHIZAKI JÚNIOR, N., 2017. A importância do planejamento logístico com foco no crescimento da demanda da cadeia produtiva de alimentos até 2050. Revista Fatec Zona Sul, vol. 3, no. 3, pp. 31-45.

MARTINELLI, L.A. and FILOSO, S., 2009. Balance between food production, biodiversity and ecosystem services in Brazil: a challenge and an opportunity. Biota Neotropica, vol. 9, no. 4, pp. 21-25. http://dx.doi.org/10.1590/S1676-06032009000400001.

MASTRORILLI, M. and ZUCARO, R., 2016. Towards sustainable use of water in rainfed and irrigated cropping systems: review of some technical and policy issues. AIMS Agriculture and Food, vol. 1, no. 3, pp. 294-314. http://dx.doi.org/10.3934/agrfood.2016.3.294.

MAYENDE, L., WILHELMI, B. and PLETSCHKE, B., 2006. Cellulases (CMCases) and polyphenol oxidases from thermophilic Bacillus spp. isolated from compost. Soil Biology E Biochemistry, vol. 38, no. 9, pp. 2963-2966. http://dx.doi.org/10.1016/j. soilbio.2006.03.019.

MENEZES-BLACKBURN, M.K., INOSTROZA, N.G., GIANFREDA, L., GREINER, R., MORA, M.L. and JORQUERA, M.A., 2016. Phytaseproducing Bacillus sp. inoculation increases phosphorus availability in cattle manure. Journal of soil Science and Plant Nutrition, vol. 16, no. 210, pp. 200-210. http://dx.doi.org/10.4067/ S0718-95162016005000016.

MENG, Q., YANG, W., MEN, M., BELLO, A., XU, X., XU, B., DENG, L., JIANG, X., SHENG, S., WU, X., HAN, Y. and ZHU, H., 2019. Microbial community succession and response to environmental variables during cow manure and corn straw composting. Frontiers in Microbiology, vol. 10, pp. 529. http://dx.doi.org/10.3389/ fmicb.2019.00529. PMid:30936861.

MILALA, M.A., SHUGABA, A., GIDADO, A., ENE, A.C. and WAFAR, J.A., 2005. Studies on the use of agricultural wastes for cellulase enzyme production by Aspergillus niger. Research Journal of Agriculture and Biological Sciences, vol. 1, no. 4, pp. 323-325.

MONDAL, T., DATTA, J.K. and MONDAL, N.K., 2017. Chemical fertilizer in conjunction with biofertilizer and vermicompost induced changes in morpho-physiological and bio-chemical traits of mustard crop. Journal of the Saudi Society of Agricultural Sciences, vol. 16, no. 2, pp. 135-144. http://dx.doi.org/10.1016/j. jssas.2015.05.001.

MORAIS, V.S., 2014. [viewed in 20 October 2016] Teoria da Granulação [online]. JSA Consultoria e Assessoria Técnica. Available from: http://www.ebah.com.br/content/ABAAAAcBcAB/teoriagranulacao

MOSIER, N., WYMAN, C., DALEC, B., ELANDER, R. and LEE, Y.Y., 2005. Features of promising technologies for pretreatment of lignocellulosic biomass. Bioresource Technology, vol. 96, no. 6, pp. 673-686. http://dx.doi.org/10.1016/j.biortech.2004.06.025. PMid: 15588770 .

NEHER, D.A., WEICHT, T.R., BATES, S.T., LEFF, J.W. and FIERER, N., 2013. Changes in bacterial and fungal communities across compost recipes, preparation methods, and composting times. PLoS One, vol. 8, no. 11, pp. e79512. http://dx.doi.org/10.1371/ journal.pone.0079512. PMid:24278144.

OLIVEIRA, F.N.S., LIMA, H.J.M. and CAJAZEIRA, J.P., 2004 [viewed in 20 October 2016]. Uso da Compostagem em Sistemas Agrícolas Orgânicos [online]. Fortaleza: Embrapa Agroindústria Tropical. 20 p. Embrapa Agroindústria Tropical. Documentos, no. 89. Available from: http://www.infoteca.cnptia.embrapa.br/ infoteca/handle/doc/418734.

ORGANISATION FOR ECONOMIC CO-OPERATION DEVELOPMENT - OECD. FOOD AND AGRICULTURE ORGANIZATION, 2015.
OCDE-FAO Perspectivas Agrícolas 2015. Paris: OECD Publishing. http://dx.doi.org/10.1787/agr_outlook-2015-es

PAIVA, C.A.O., OLIVEIRA, M.C., MARRIEL, I.E., SOUZA. F.A., VALICENTE, F.H. and COTA, L.V., 2013 [viewed in 20 October 2016]. Manual de gestão da Coleção de Microrganismos Multifuncionais e Fitopatogênicos da Embrapa Milho e Sorgo (CMMF) [online]. Sete Lagoas: Embrapa Milho e Sorgo. 41 p. Série Documentos, no. 153. Available from: https://ainfo.cnptia.embrapa.br/digital/ bitstream/item/90120/1/doc-153.pdf

PANIKOV, N.S., POPOVA, N.A., DOROFEEV, A.G., NICOLAEVE-YU, A. and VERKHOVTSEVA, N.V., 2003. Growth of the thermophilic bacteria Geobacillus urdicus as a function of temperature and pH: an SCM-Based kinetic analysis. Microbiology, vol. 72, no. 3, pp. 277-284. http://dx.doi.org/10.1023/A:1024239713941. PMid:12901005.

PARTANEN, P., HULTMAN, J., PAULIN, L., AUVINEN, P. and ROMANTSCHUK, M., 2010. Bacterial diversity at different stages of the composting process. Mikrobiologiia, vol. 10, no. 94, pp. 1-13. PMid:20350306.

PEREIRA, L.S., CORDERY, I. and IACOVIDES, I., 2012. Improved indicators of water use performance and productivity for sustainable water conservation and saving. Agricultural Water Management, vol. 108, pp. 39-51. http://dx.doi.org/10.1016/j. agwat.2011.08.022.

PHILLIPPY, B.Q., 2006. Transport of calcium across Caco-2 cells in the presence of inositol hexakisphosphate. Nutrition Research (New York, N.Y.), vol. 26, no. 3, pp. 146-149. http://dx.doi. org/10.1016/j.nutres.2006.02.008.

PIAZZA, S., HOUBRAKEN, J., MEIJER, M., CECCHI, G., KRAAK, B., ROSA, E. and ZOTTI, M., 2020. Thermotolerant and thermophilic mycobiota in different steps of compost maturation. Microorganisms, vol. 8, no. 6, pp. 880. http://dx.doi.org/10.3390/ microorganisms8060880. PMid:32545162.

PIKOVSKAYA, R.I., 1948. Mobilization of phosphorous in soil in connection with vital activity of some microbial species. Mikrobiologya, vol. 17, pp. 362-370.

PIVOTO, D., WAQUIL, P.D., TALAMINI, E., FINOCCHIO, C.P.S., DALLA CORTE, V.F. and DE VARGAS MORES, G., 2018. Scientific development of smart farming technologies and their application in Brazil. Information Processing in Agriculture, vol. 5, no. 1, pp. 21-32. http://dx.doi.org/10.1016/j.inpa.2017.12.002.

RADL, V., KINDLER, R., WELZL, G., ALBERT, A., WILKE, B.M., AMELUNG, W. and SCHLOTER, M., 2015. Drying and rewetting events change the response pattern of nitrifiers but not of denitrifiers to the application of manure containing antibiotic in soil. Applied Soil Ecology, vol. 95, pp. 99-106. http://dx.doi.org/10.1016/j. apsoil.2015.06.016.

RAVINDRAN, P.N., SASIKUMAR, B., GEORGE, J.K., RATNAMBAL, M.J., NIRMALBABU, K., ZACHARIAH, T.J. and NAIR, R.R. 1994. Genetic recourses of ginger (Zingiber officinale Rosc.) and its conservation in India. Plant Genetic Resources News Letter, vol. 98, pp. 1-4.

REBOLLIDO, R., MARTÍNEZY, J., AGUILERA, Y., MELCHOR, K. and KÖRNER, I., 2008. Microbial populations during composting process of organic fraction of municipal solid waste. Applied Ecology and Environmental Research, vol. 6, no. 3, pp. 61-67. http://dx.doi.org/10.15666/aeer/0603_061067.

REY, M.W., RAMAIYA, P., NELSON, B.A., BRODY-KARPIN, S.D., ZARETSKY, E.J., TANG, M., LOPEZ DE LEON, A., XIANG, H., GUSTI, V., CLAUSEN, I.G., OLSEN, P.B., RASMUSSEN, M.D., ANDERSEN, J.T., JØRGENSEN, P.L., LARSEN, T.S., SOROKIN, A., BOLOTIN, A., LAPIDUS, A., GALLERON, N., EHRLICH, S.D. and BERKA, R.M., 2004. Complete genome sequence of the industrial bacterium Bacillus licheniformis and comparisons with closely related 
Bacillus species. Genome Biology, vol. 5, no. 10, pp. R77. http:// dx.doi.org/10.1186/gb-2004-5-10-r77. PMid:15461803.

RIBEIRO, N.Q., SOUZA, T.P., COSTA, L.M.A.S., CASTRO, C.P. and DIAS, E.S., 2017. Microbial additives in the composting process. Ciência e Agrotecnologia, vol. 41, no. 2, pp. 159-168. http:// dx.doi.org/10.1590/1413-70542017412038216.

RICHARDSON, A.E., GEORGE, T.S., HENS, M. and SIMPSON, R.J. 2005. Utilization of soil organic phosphorus by higher plants. In: B.L. TURNER, E. FROSSARD, D. BALDWIN, ed. Organic Phosphorus in the Environment. CABI Publishing, pp. 165-184 http://dx.doi.or g/10.1079/9780851998220.0165.

ROCHA, T.B., 2010. Isolamento, identificação e caracterização enzimática de uma bactéria de fonte termal do Cerrado. Brasília: Universidade de Brasília, 124 p. Dissertação Mestrado em Biologia Molecular.

SELLE, P.H., RAVINDRAN, V., CALDWELL, A. and BRYDEN, W.L., 2000. Phytate and phytase: consequences for protein utilization. Nutrition Research Reviews, vol. 13, no. 2, pp. 255-278. http:// dx.doi.org/10.1079/095442200108729098. PMid:19087442.

SHAIR, O.H.M., 2014. Heat resisting bacteria from soil: A simple method for isolation and extraction of DNA. Journal of Pure $\mathcal{E}$ Applied Microbiology, vol. 8, pp. 1003-1007.

SHUKOR, J.A., OMAR, M.F., KASIM, M.M., JAMALUDIN, M.H.B. and NAIM, M.A., 2018. Assessment of composting technologies for organic waste management. International Journal of Technology, vol. 9, no. 8, pp. 1579. http://dx.doi.org/10.14716/ijtech.v9i8.2754.

SILVA, M.C., COSTA, F.R., LEANDRO, W.M., JÚNIOR, A.F.L., BRITO, G.S. and SILVA, L.R. 2015 Eficiência de uso de (FMB), vol.8, n. 5, pp. 46-139.

SIU-RODAS, Y., CALIXTO-ROMO, M.L.A., GUILLÉN-NAVARRO, K., SÁNCHEZ, J.E., ZAMORA-BRISEÑO, J.A. and AMAYA-DELGADO, L., 2018. Bacillus subtilis with endocellulase and exocellulase activities isolated in the thermophilic phase from composting with coffee residues. Revista Argentina de Microbiologia, vol. 50 no. 3, pp. 234-243. http://dx.doi.org/10.1016/j.ram.2017.08.005. PMid:29289440.

SONG, C., LI, M., JIA, X., WEI, Z., ZHAO, Y., XI, B., ZHU, C. and LIU, D., 2014. Comparison of bacterial community structure and dynamics during the thermophilic composting of different types of solid wastes: anaerobic digestion residue, pig manure and chicken manure. Microbial Biotechnology, vol. 7, no. 5, pp. 424433. http://dx.doi.org/10.1111/1751-7915.12131. PMid:24963997.

SONUNE, N. and GARODE, A., 2018. Isolation, characterization and identification of extracellular enzyme producer Bacillus licheniformis from municipal wastewater and evaluation of their biodegradability. Biotechnology Research and Innovation, vol. 2, no. 1, pp. 37-44. http://dx.doi.org/10.1016/j.biori.2018.03.001.

SOUZA, A.N. and MARTINS, M.L.L., 2001. Isolation, properties and kinetics of growth of a thermophilic Bacillus. Brazilian Journal of Microbiology, vol. 32, no. 4, pp. 271-275. http://dx.doi. org/10.1590/S1517-83822001000400003.

UVAROV, R., BRIUKHANOV, A. and SHALAVINA, E., 2016. Study results of mass and nutrient loss in technologies of different composting rate: case of bedding poultry manure. In: 15th International Scientific Conference Engineering for rural development, May 25-27. Jelgava, Letônia: Latvia University of Agriculture, pp. 851-857.
VEGRO, C.L.R. 2018. [viewed 16 march 2021] Mercado de Fertilizantes: aumento das importações preocupa. Instituto de Economia Agrícola [online], vol. 13, no. 4, pp. 1-5. Available from: http://www.iea.sp.gov.br/ftpiea/AIA/AIA-16-2018.pdf

VILLAR, I., ALVES, D., GARRIDO, J. and MATO, S., 2016. Evolution of microbial dynamics during the maturation phase of the composting of different types of waste. Waste Management, vol. 54, pp. 83-92. http://dx.doi.org/10.1016/j.wasman.2016.05.011. PMid:27236404.

WINDISH, W.W. and MHATRE, N.S., 1965. Microbial amylases. In: W.U. WAYNE, ed. Advances in Applied Microbiology. New York: Academic Press, vol. 7, pp. 273-304. https://doi.org/10.1016/ S0065-2164(08)70389-7.

WITHERS, P.J.A., RODRIGUES, M., SOLTANGHEISI, A., CARVALHO, T.S., GUILHERME, L.R.G., BENITES, V.M., GATIBONI, L.C., SOUSA, D.M.G., NUNES, R.S., ROSOLEM, C.A., ANDREOTE, F.D. and OLIVEIRA, A. Jr., 2018. Transitions to sustainable management of phosphorus in Brazilian agriculture. Scientific Reports, vol. 8, no. 1, pp. 2537. http://dx.doi.org/10.1038/s41598-018-20887-z. PMid:29416090.

WU, X., WANG, Y., TONG, B., CHEN, X. and CHEN, J., 2018. Purification and biochemical characterization of a thermostable and acid-stable alpha-amylase from Bacillus licheniformis B4-423. International Journal of Biological Macromolecules, vol. 109, pp. 329-337. http://dx.doi.org/10.1016/j.ijbiomac.2017.12.004. PMid:29233713.

XU, J., LU, Y., SHAN, G., HE, X.S., HUANG, J. and LI, Q., 2019. Inoculation with Compost-Born Thermophilic Complex Microbial Consortium Induced Organic Matters Degradation While Reduced Nitrogen Loss During Co-Composting of Dairy Manure and Sugarcane Leaves. Waste and Biomass Valorization, vol. 10, no. 9, pp. 2467-2477. http://dx.doi.org/10.1007/s12649018-0293-y.

YAKIMOV, M.M., TIMMIS, K.N., WRAY, V. and FREDRICKSON, A.L., 1995. Characterization of a new lipopeptide surfactant produced by thermotolerant and halotolerant subsurface Bacillus licheniformis BAS50. Applied and Environmental Microbiology, vol. 61, no. 5, pp. 1706-1713. http://dx.doi.org/10.1128/aem.61.5.17061713.1995. PMid:7646007.

ZAINUDIN, M.H., HASSAN, M.A., TOKURA, M. and SHIRAI, Y., 2013. Indigenous cellulolytic and hemicellulolytic bacteria enhanced rapid co-composting of lignocellulose oil palm empty fruit bunch with palm oil mill effluent anaerobic sludge. Bioresource Technology, vol. 47, pp. 632-635. http://dx.doi.org/10.1016/j. biortech.2013.08.061. PMid:24012093.

ZAKARYA, I.A., KHALIB, S.N.B.B. and RAMZI, N.M., 2018. Effect of $\mathrm{pH}$, temperature and moisture content during composting of rice straw burning at different temperature with food waste and effective microorganisms. E3S Web of Conferences, vol. 34, pp. 1-8. https://doi.org/10.1051/e3sconf/20183402019.

ZELDES, B.M., KELLER, M.W., LODER, A.J., STRAUB, C.T., ADAMS, M.W.W. and KELLY, R.M., 2015. Extremely thermophilic microorganisms as metabolic engineering platforms for production of fuels and industrial chemicals. Frontiers in Microbiology, vol. 6, pp. 1209. http://dx.doi.org/10.3389/ fmicb.2015.01209. PMid:26594201. 